\title{
Erratum
}

\section{Erratum to: Effect of Er'zhi Pill (二至丸) on Improving Cerebral Nerve Cell Apoptosis in Aging Rats}

\author{
GAO Hui-li (高会丽),WANG Dan-qiao (王丹巧), WANG Xiao-yan (汪晓燕), WANG Zhi-guo (王志国), \\ WANG Xiang-ming (王香明), WU Zhao-en (吴兆恩), LIU Hong (刘 红), \\ MA Yan-yan (马琰岩), NIU Xiao-hong (牛晓红), and Li Lian-da (李连达)
}

Erratum to: Chin J Integr Med 2010 Dec;16(6):504-509

DOI: $10.1007 / s 11655-010-0565-2$

In the original version of the article, the pictures in Figure1 were rotated. The correct version is given below.
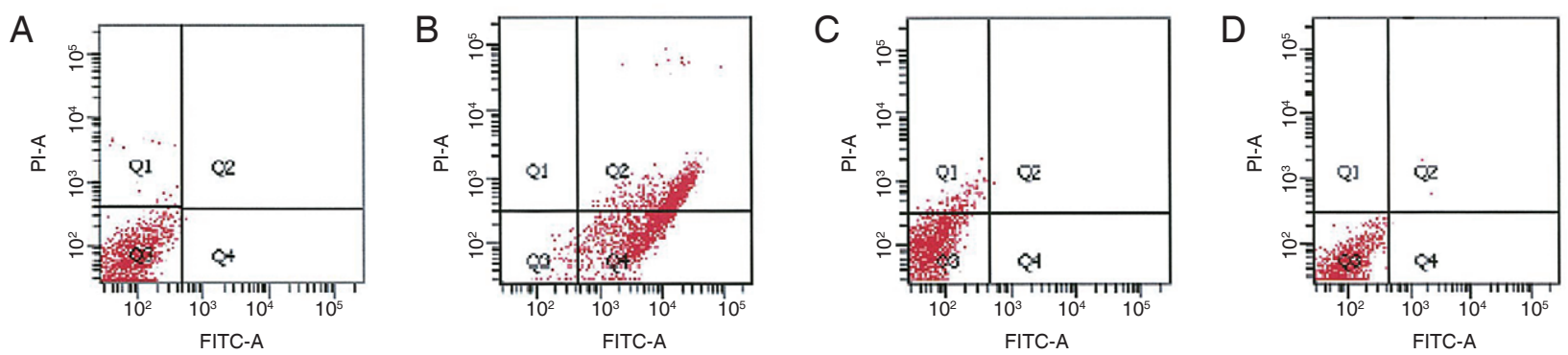

Figure 1. Apoptosis Rate in Various Groups

Notes: A: the normal control group; B: the model group; C: the EZP group; D: the vitamins group 